\title{
Development of a Five Domains Integrated Content-Based EFL Curriculum for Pre-service Teacher Education: With Focus on Promoting Students' Interaction in English
}

\author{
Hiroki Yoshida
}

\begin{abstract}
Elementary school teachers and secondary school English teachers in Japan are now facing a substantial reformation of the system of English education. The Japanese Ministry of Education, Culture, Sports, Science, and Technology (MEXT) has announced a vision for a full-scale development of a new English education curriculum that is timed with the 2020 Tokyo Olympics. Elementary schools are to conduct English Language Activities classes once to twice a week for third and fourth graders, and to conduct English classes as a subject three times a week for fifth and sixth graders. Lower secondary schools are to teach English classes in English. The MEXT has also stipulated teacher training colleges to revise the "Courses of Study" and the pre-service teaching standard curriculum, and to integrate subjects related with English pedagogy into subjects related with specialized knowledge in English. Therefore, this study purposed to develop and examine the validity of a five domains integrated content-based language learning curriculum for pre-service English teacher education for Japanese university students.
\end{abstract}

Index Terms-Five domains integrated approach, content-based language learning, interaction in English, curriculum development, pre-service teacher education.

\section{INTRODUCTION}

Elementary and secondary schools in Japan develop school curricula and classroom lessons based on the national education guideline "Courses of Study." It is specified in the Regulations for the Enforcement of the School Education Act, which were issued in 1947 that curricula in elementary and secondary schools in Japan have to meet standards established by the Minister of Education in its "Courses of Study."

The first "Courses of Study (Tentative Draft)" was announced in 1947 and the respective "Courses of Study" for each subject: Japanese language, social studies, mathematics, science, music, physical education, arts and crafts, home economics, and free study followed it. Social Studies formed the core of the "Courses of Study," with the purpose of teaching students about community life, and promoting their social skills and attitude to adapt to their society [1]. Since then, the "Courses of Study" has been revised seven times.

In 1996, the sixth "Courses of Study" was revised following the recommendations of the Central Council for

Manuscript received May 20, 2017; revised August 13, 2017. This work was supported by JSPS KAKENHI Grant Number 26370729.

Hiroki Yoshida is with Kanto Gakuin University, Yokohama, Japan (e-mail: hy4@kanto-gakuin.ac.jp).
Education. The Central Council for Education reported in "The Model for Japanese Education in the Perspective of the 21st Century" to develop students' "zest for living" through autonomous learning. [2], [3]" "Zest of living" means well-balanced competencies of 1) solid academic capabilities, 2) well-rounded character, and 3) healthy body in order to live in the rapid changing society [4].

Japanese Education Minister Hakubun Shimomura proposed in the "Curriculum Standards for Elementary and Secondary Education: Inquiry" to revise the "Courses of Study" and the pre-service teaching standard curriculum on November 22th, 2014 [5]. Education Minister tasked the Central Council for Education to revise the standard curriculum by the end of AY2016, and to implement the revised standard curriculum from April 1st, 2019.

On December 21st 2015, the Central Council for Education suggested in "Promoting School Teachers' Qualities and Abilities that Lead the Future of Education: Report [6]" to strengthen the connection of the Contents of School Subjects group and English Teaching Methods. The council insisted to integrate subjects related with English Teaching Methods into the Contents of School Subjects group.

\section{A. Reformation of the English Education System in Japan}

English teachers in Japan are facing a large scale reformation of the system of English education. The Japanese Ministry of Education, Culture, Sports, Science, and Technology (MEXT) has announced a vision for a full-scale deployment of new English education that is timed with the 2020 Tokyo Olympics.

On June 30th, 2011, the Commission on the Development of Foreign Language Proficiency proposed in the "Five Proposals and Specific Measures for Developing Proficiency in English for International Communication" to "promote students' awareness of necessity of English in the global society, and stimulating motivation for language learning," provide "students with more opportunities to use English through effective utilization of ALTs, ICT and other means," and reinforce "English skills and instruction abilities of English teachers, [7]"

On December 13th, 2013, the Education Minister stipulated in the "English Education Reform Plan Corresponding to Globalization" that English education should being from 3rd grade, and 3rd and 4th grade students should participate in English language activities one to two times a week, with the purpose of nurturing the foundation of communication skills. Furthermore, the Minister announced that 5 th and 6th grade students should be taught three times a 
week as official English language subject classes, with the purpose of nurturing basic English language skills [8]. In order to meet the purpose of English education in elementary education, the MEXT proposed to 1) promote elementary school teachers' English teaching skills, 2) develop and promote materials for teacher education, and 3) expand placement of assistant language teachers, [8].

As for English education in secondary education, the Education Minister announced in the "English Education Reform Plan Corresponding to Globalization" to "nurture the ability to understand familiar topics" and to "carry out simple information exchanges" in lower secondary schools, and to "nurture the ability to understand abstract contents for a wide range of topics and the ability to fluently communicate with English speaking persons" and to conduct classes "in English with high-level linguistic activities" such as doing presentations, debates, negotiations and to "describe familiar matters in English" in upper secondary schools [8]. So as to meet the purpose of English education in secondary education, the MEXT suggested to 1) develop English education promotion leaders in secondary schools, 2) Promote secondary school English subject teachers' teaching skills, 3) promote placement and utilization of Assistant Language Teachers, and to 4) develop and promote Information and Communication Technology-based teaching materials for teacher education.

On December 21st, 2015, the Central Council of Education proposed in the "Promotion of School Teachers' Qualities and Abilities for School Education in the Future: Report" that universities should improve pre-service teachers knowledge and skills in English education and English as a subject. The Council also suggested universities and boards of education to cooperate to develop core curricula for pre-service and in-service teacher education in English education [9].

Thus, English teachers are confronted with major reformation of the system of English teacher education and training as well as English education. Therefore, this study purposes to research policies and history of lower secondary pre-service English teacher education in Japan and to analyze what is needed to promote good teachers and classroom lessons in lower secondary schools.

\section{B. Pre-service Teacher Education in Japan}

Currently, pre-service teacher education is provided by universities and colleges in Japan. Universities develop pre-service teacher education curricula and courses that meet the standards regulated by the Education Personnel Certification Act.

The Education Personnel Certification Act was enacted on May 31st, 1949 with the principle of "teacher education at university level" and "open system policy," where any national, public or private university/college could provide teacher education courses if its curriculum is qualified by the MEXT. Under the "open system policy," teacher education is not limited to teacher training universities or faculties of education. The "open system policy" is based on the philosophy that school teachers must study liberal arts in order to promote their knowledge, generic skills, and wisdom as the basis for their lives in the teaching profession.
Therefore, English teacher education is conducted not only in faculties of education, but also in faculties such as foreign languages, literature, humanities, liberal arts, communication, and culture.

The curriculum standard for pre-service teacher education was last revised in 1998. Table I shows the categories and course details of the present curriculum standard, and credit unites needed for a secondary English teachers' license [10].

TABLE I: PRESENT CURRICULUM STANDARD FOR PRE-SERVICE TEACHER EDUCATION FOR SECONDARY EDUCATION (ENGLISH)

\begin{tabular}{|c|c|c|}
\hline Categories & Course Details & Credits \\
\hline \multicolumn{2}{|l|}{ English Linguistics } & \multirow{4}{*}{20} \\
\hline \multicolumn{2}{|l|}{ English Literature } & \\
\hline \multicolumn{2}{|l|}{ English Communication } & \\
\hline \multicolumn{2}{|c|}{ Cross-cultural Understanding } & \\
\hline \multicolumn{2}{|c|}{ Subjects for the Meaning of Teachers } & 2 \\
\hline \multirow{4}{*}{$\begin{array}{l}\text { Basic Theories in } \\
\text { Education }\end{array}$} & Principles and History of Education & \multirow{4}{*}{6} \\
\hline & Educational Psychology & \\
\hline & $\begin{array}{l}\text { Developmental and Educational } \\
\text { Psychology }\end{array}$ & \\
\hline & $\begin{array}{l}\text { Educational Sociology, Educational } \\
\text { Systems, and Educational } \\
\text { Administration }\end{array}$ & \\
\hline \multirow{5}{*}{$\begin{array}{l}\text { Curriculum Studies and } \\
\text { Educational Pedagogy }\end{array}$} & $\begin{array}{l}\text { Curriculum Studies for Secondary } \\
\text { Education }\end{array}$ & \multirow{5}{*}{12} \\
\hline & English Teaching Methods & \\
\hline & $\begin{array}{l}\text { Theories and Methods of Moral } \\
\text { Education }\end{array}$ & \\
\hline & Extra-curricular Activities & \\
\hline & Educational Technology & \\
\hline \multirow{2}{*}{$\begin{array}{l}\text { Subjects for } \\
\text { Educational Guidance } \\
\text { and Counseling }\end{array}$} & $\begin{array}{l}\text { Theories of Student Guidance and } \\
\text { Career Guidance }\end{array}$ & \multirow[t]{2}{*}{4} \\
\hline & Educational Counseling & \\
\hline \multicolumn{2}{|l|}{ Teaching Practice } & 5 \\
\hline \multicolumn{2}{|c|}{ Educational Practice Seminar } & 2 \\
\hline \multicolumn{2}{|c|}{ University-based Subjects } & 8 \\
\hline
\end{tabular}

Japanese Education Minister Hakubun Shimomura proposed in the "Curriculum Standards for Elementary and Secondary Education: Inquiry" to revise the "Courses of Study" and the pre-service teaching standard curriculum on November 22th, 2014 [5]. Education Minister tasked the Central Council for Education to revise the standard curriculum by the end of AY2016, and to implement the revised standard curriculum from April 1st, 2019.

On December 21st 2015, the Central Council for Education suggested in "Promoting School Teachers' Qualities and Abilities that Lead the Future of Education: Report [6]" to strengthen the connection of the Contents of School Subjects group and English Teaching Methods. The council insisted to integrate subjects related with English Teaching Methods into the Contents of School Subjects group.

Table II shows the subject groups and course detail of the next standard curriculum for lower secondary English teacher education, and credit units required for a teachers' license.

TABLE II: NEXT CURRICULUM STANDARD FOR PRE-SERVICE TEACHER EDUCATION FOR SECONDARY EDUCATION (ENGLISH)

\begin{tabular}{|l|l|c|}
\hline \multicolumn{1}{|c|}{ Categories } & \multicolumn{1}{|c|}{ Course Details } & Credits \\
\hline $\begin{array}{l}\text { Contents and Methods } \\
\text { of School Subjects }\end{array}$ & English Linguistics & \multirow{2}{*}{28} \\
\cline { 2 - 2 } & English Literature & \\
\hline
\end{tabular}




\begin{tabular}{|c|c|c|}
\hline & English Communication & \\
\hline & Cross-cultural Understanding & \\
\hline & English Teaching Methods & \\
\hline \multirow{6}{*}{$\begin{array}{l}\text { Basic Theories in } \\
\text { Education }\end{array}$} & Principles and History of Education & \multirow{6}{*}{10} \\
\hline & Meaning of Teachers & \\
\hline & $\begin{array}{l}\text { Educational Sociology, Educational } \\
\text { Systems, and Educational } \\
\text { Administration }\end{array}$ & \\
\hline & $\begin{array}{l}\text { Developmental and Educational } \\
\text { Psychology }\end{array}$ & \\
\hline & Special Needs Education & \\
\hline & $\begin{array}{l}\text { Curriculum Studies for Secondary } \\
\text { Education }\end{array}$ & \\
\hline \multirow{6}{*}{$\begin{array}{l}\text { Subjects for } \\
\text { Educational Pedagogy, } \\
\text { Guidance and } \\
\text { Counseling }\end{array}$} & $\begin{array}{l}\text { Theories and Methods of Moral } \\
\text { Education }\end{array}$ & \multirow{6}{*}{10} \\
\hline & $\begin{array}{l}\text { Teaching Methods of the "Period for } \\
\text { Integrated Studies" }\end{array}$ & \\
\hline & Extra-curricular Activities & \\
\hline & Educational Technology & \\
\hline & Educational Counseling & \\
\hline & $\begin{array}{l}\text { Theories of Student Guidance and } \\
\text { Career Guidance }\end{array}$ & \\
\hline \multirow{2}{*}{$\begin{array}{l}\text { Subjects for } \\
\text { Educational Practice }\end{array}$} & Teaching Practice & \multirow{2}{*}{7} \\
\hline & Educational Practice Seminar & \\
\hline $\begin{array}{l}\text { University-based } \\
\text { Subjects }\end{array}$ & & 4 \\
\hline
\end{tabular}

\section{Introduction of the Core Curriculum for Elementary} and Secondary Pre-service English Teacher Education

In order to cope with the revision of the standard curriculum for teacher education and the "Courses of Study," Tokyo Gakugei University announced the Core Curriculum for English education and English as a subject in elementary and secondary education on March 31st, 2016 [11]. After a formative evaluation, the Core Curriculum was revised and re-announced on March 20th, 2017 [12]. Table III shows the current pre-service teacher education Core Curriculum for English education in secondary schools.

TABLE III: CORE CURRICULUM FOR ENGLISH EDUCATION: PRE-SERVICE TEACHER EDUCATION FOR SECONDARY EDUCATION (SOURCE: TOKYO GAKUGEI UNIVERSITY, 2017, TRANSLATED BY AUTHOR)

\begin{tabular}{|c|c|c|}
\hline $\begin{array}{l}\text { Subject } \\
\text { Groups }\end{array}$ & Categories & Course Details \\
\hline \multirow{19}{*}{$\begin{array}{l}\text { English } \\
\text { Pedagogy } \\
\text { ( } 8 \text { credit units) }\end{array}$} & \multirow{4}{*}{$\begin{array}{l}\text { Curriculum / } \\
\text { Syllabus }\end{array}$} & "Courses of Study" \\
\hline & & School Textbooks \\
\hline & & Objectives and Plans \\
\hline & & Educational Continuity \\
\hline & \multirow{14}{*}{$\begin{array}{l}\text { Teaching Skills and } \\
\text { Methods }\end{array}$} & Listening \\
\hline & & Reading \\
\hline & & \begin{tabular}{|l|} 
Speaking (Interaction and \\
Presentation) \\
\end{tabular} \\
\hline & & Writing \\
\hline & & Phonics \\
\hline & & Alphabets \\
\hline & & Lexicon \\
\hline & & Grammar \\
\hline & & \begin{tabular}{|l|} 
Cross-cultural Understanding \\
\end{tabular} \\
\hline & & \begin{tabular}{|l|} 
Study of Teaching Materials \\
\end{tabular} \\
\hline & & ICT Integration \\
\hline & & ALTs and Team Teaching \\
\hline & & Interaction in English \\
\hline & & $\begin{array}{l}\text { Instruction Based on Students' Traits } \\
\text { and Proficiency Levels }\end{array}$ \\
\hline & Instructional Design & Instructional Design Based on \\
\hline
\end{tabular}

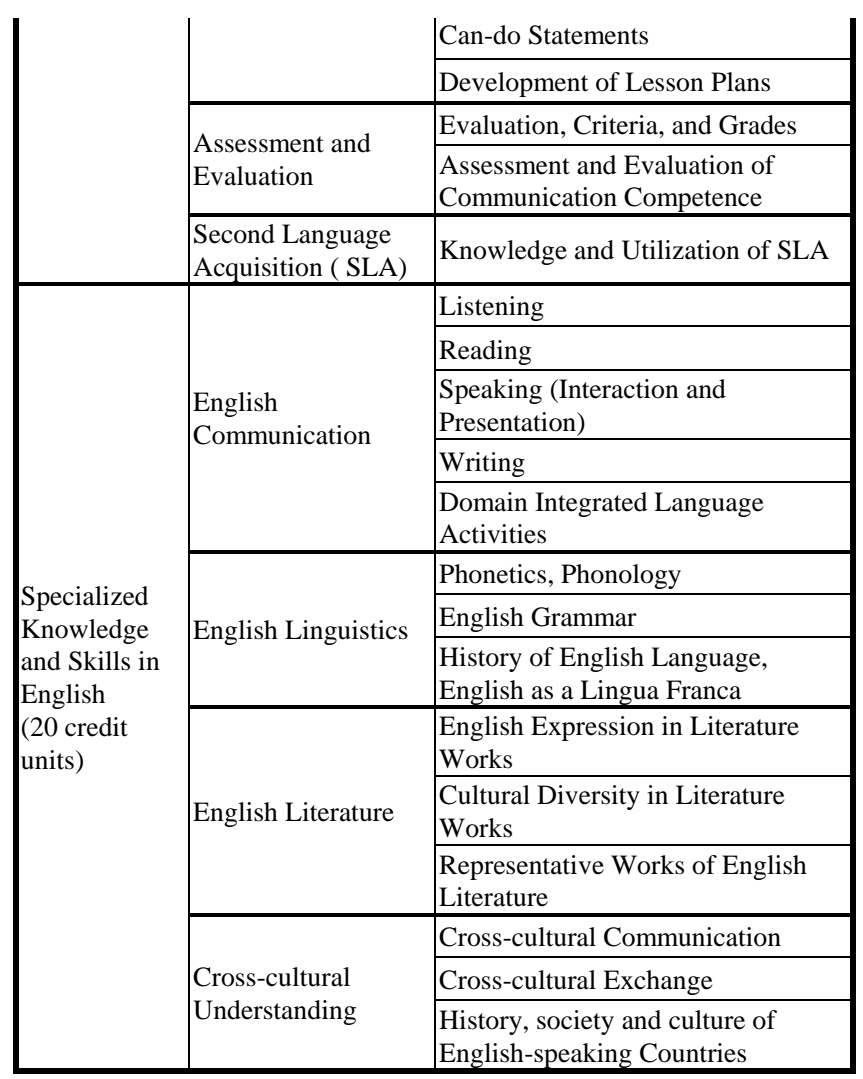

Universities which conduct pre-service elementary teacher education and secondary English teacher education are to revise their curriculum by March 31st 2018 response to the Core Curriculum.

\section{PURPOSE}

The purpose of the study is to develop and examine the validity of a five domains integrated content-based language learning curriculum for Japanese pre-service teachers.

\section{ANALYSIS OF THE CURRENT CURRICULUM}

The five domains integrated content-based EFL curriculum was developed in July, 2016.

Table IV shows the EFL curriculum for pre-service education for secondary education (English Department) which was developed by the Department of English Language of a private university in Shizuoka, Japan.

TABLE IV: EFL CURRICULUM FOR PRE-SERVICE TEACHER EDUCATION FOR SECONDARY EDUCATION (DEPARTMENT OF ENGLISH LANGUAGE)

\begin{tabular}{|c|c|c|c|c|c|}
\hline \multirow[b]{2}{*}{ Categories } & \multirow[b]{2}{*}{ Course Details } & \multirow[b]{2}{*}{ Semester } & \multicolumn{2}{|c|}{ Credits } & \multirow[b]{2}{*}{ Form } \\
\hline & & & $\begin{array}{c}\text { Compulso } \\
\text { ry }\end{array}$ & Elective & \\
\hline \multirow{6}{*}{$\begin{array}{l}\text { English } \\
\text { Linguistics }\end{array}$} & $\begin{array}{l}\text { Communicative } \\
\text { Writing II A }\end{array}$ & 3 & & 2 & Lecture \\
\hline & $\begin{array}{l}\text { English Phonetics } \\
\text { A }\end{array}$ & 3 & 2 & & Lecture \\
\hline & \begin{tabular}{|l|} 
English Phonetics \\
B
\end{tabular} & 4 & & 2 & Lecture \\
\hline & $\begin{array}{l}\text { History of English } \\
\text { Language A }\end{array}$ & 5 & 2 & & Lecture \\
\hline & $\begin{array}{l}\text { History of English } \\
\text { Language B } \\
\end{array}$ & 6 & & 2 & Lecture \\
\hline & $\begin{array}{l}\text { English Education } \\
\text { for Children A }\end{array}$ & 5 & & 2 & Lecture \\
\hline
\end{tabular}




\begin{tabular}{|c|c|c|c|c|c|}
\hline & $\begin{array}{l}\text { English Education } \\
\text { for Children B }\end{array}$ & 6 & & 2 & Lecture \\
\hline & \begin{tabular}{|l|} 
English \\
Educational \\
Technology A \\
\end{tabular} & 7 & & 2 & Lecture \\
\hline & \begin{tabular}{|l} 
English \\
Educational \\
Technology B
\end{tabular} & 8 & & 2 & Lecture \\
\hline \multirow{5}{*}{$\begin{array}{l}\text { English } \\
\text { Literature }\end{array}$} & $\begin{array}{l}\text { Intensive Reading } \\
\text { II A }\end{array}$ & 3 & & 2 & Lecture \\
\hline & $\begin{array}{l}\text { History of English } \\
\text { Literature A } \\
\end{array}$ & 3 & 2 & & Lecture \\
\hline & $\begin{array}{l}\text { History of English } \\
\text { Literature B }\end{array}$ & 4 & & 2 & Lecture \\
\hline & \begin{tabular}{|l|} 
History of \\
American \\
Literature A \\
\end{tabular} & 5 & 2 & & Lecture \\
\hline & \begin{tabular}{|l} 
History of \\
American \\
Literature B \\
\end{tabular} & 6 & & 2 & Lecture \\
\hline \multirow{3}{*}{$\begin{array}{l}\text { English } \\
\text { Communicatio } \\
n\end{array}$} & Listening II A & 3 & & 1 & Seminar \\
\hline & \begin{tabular}{|l|} 
Oral \\
Communication II \\
A
\end{tabular} & 3 & 1 & & Seminar \\
\hline & \begin{tabular}{|l|} 
Oral \\
Communication II \\
B
\end{tabular} & 4 & 1 & & Seminar \\
\hline \multirow{6}{*}{$\begin{array}{l}\text { Cross-cultural } \\
\text { Understanding }\end{array}$} & English Culture A & 5 & & 2 & Lecture \\
\hline & English Culture B & 6 & & 2 & Lecture \\
\hline & \begin{tabular}{|l|} 
American Culture \\
A
\end{tabular} & 5 & 2 & & Lecture \\
\hline & \begin{tabular}{|l} 
American Culture \\
B
\end{tabular} & 6 & & 2 & Lecture \\
\hline & \begin{tabular}{|l|} 
Comparative \\
Children Culture \\
A \\
\end{tabular} & 5 & & 2 & Lecture \\
\hline & \begin{tabular}{|l|} 
Comparative \\
Children Culture \\
B
\end{tabular} & 6 & & 2 & Lecture \\
\hline $\begin{array}{l}\text { Subjects for } \\
\text { the Meaning of } \\
\text { Teachers }\end{array}$ & $\begin{array}{l}\text { Introduction to } \\
\text { School Education }\end{array}$ & 3 & 2 & & Lecture \\
\hline \multirow{6}{*}{$\begin{array}{l}\text { Basic Theories } \\
\text { in Education }\end{array}$} & $\begin{array}{l}\text { Principle of } \\
\text { Education }\end{array}$ & 4 & 2 & & Lecture \\
\hline & \begin{tabular}{|l|} 
History of \\
Education \\
\end{tabular} & 6 & & 2 & Lecture \\
\hline & \begin{tabular}{|l} 
Educational \\
Psychology
\end{tabular} & 5 & 2 & & Lecture \\
\hline & $\begin{array}{l}\text { Developmental } \\
\text { Psychology }\end{array}$ & 3 & & 2 & Lecture \\
\hline & $\begin{array}{l}\text { Educational } \\
\text { Sociology } \\
\end{array}$ & 6 & 2 & & Lecture \\
\hline & $\begin{array}{l}\text { Theories of } \\
\text { Lifelong } \\
\text { Education }\end{array}$ & 7 & & 2 & Lecture \\
\hline \multirow{8}{*}{$\begin{array}{l}\text { Curriculum } \\
\text { Studies and } \\
\text { Educational } \\
\text { Pedagogy }\end{array}$} & \begin{tabular}{|l|} 
Curriculum \\
Studies for \\
Secondary \\
Education \\
\end{tabular} & 3 & & 2 & Lecture \\
\hline & \begin{tabular}{|l|} 
English Education \\
I
\end{tabular} & 5 & 2 & & Lecture \\
\hline & $\begin{array}{l}\text { English Education } \\
\text { II }\end{array}$ & 6 & 2 & & Lecture \\
\hline & $\begin{array}{l}\text { English Education } \\
\text { III }\end{array}$ & 7 & & 2 & Lecture \\
\hline & \begin{tabular}{|l|} 
English Education \\
IV
\end{tabular} & 8 & & 2 & Lecture \\
\hline & \begin{tabular}{|l|} 
Theories and \\
Methods of Moral \\
Education \\
\end{tabular} & 6 & 2 & & Lecture \\
\hline & \begin{tabular}{|l|} 
Extra-curricular \\
Activities
\end{tabular} & 7 & 2 & & Lecture \\
\hline & \begin{tabular}{|l|} 
Educational \\
Technology \\
\end{tabular} & 5 & 2 & & Lecture \\
\hline $\begin{array}{l}\text { Subjects for } \\
\text { Educational }\end{array}$ & $\begin{array}{l}\text { Theories of } \\
\text { Student Guidance }\end{array}$ & 6 & 2 & & Lecture \\
\hline
\end{tabular}

\begin{tabular}{|c|c|c|c|c|c|}
\hline \multirow[t]{2}{*}{$\begin{array}{l}\text { Guidance and } \\
\text { Counseling }\end{array}$} & $\begin{array}{l}\text { and Career } \\
\text { Guidance }\end{array}$ & & & & \\
\hline & \begin{tabular}{|l} 
Educational \\
Counseling
\end{tabular} & 8 & 2 & & Lecture \\
\hline \multirow{3}{*}{$\begin{array}{l}\text { Subjects for } \\
\text { Educational } \\
\text { Practice }\end{array}$} & \begin{tabular}{|l|} 
Preliminary \\
Course for \\
Teaching Practice \\
\end{tabular} & 6 & 1 & & Seminar \\
\hline & Teaching Practice & 7 & 4 & & Training \\
\hline & \begin{tabular}{|l|} 
Educational \\
Practice Seminar
\end{tabular} & 8 & 2 & & Seminar \\
\hline \multirow{6}{*}{$\begin{array}{l}\text { University } \\
\text {-based } \\
\text { Subjects }\end{array}$} & Volunteer Studies & 3 & & 2 & Lecture \\
\hline & \begin{tabular}{|l|} 
School \\
Management and \\
Libraries \\
\end{tabular} & 5 & & 2 & Lecture \\
\hline & $\begin{array}{l}\text { School Libraries } \\
\text { and Media }\end{array}$ & 4 & & 2 & Lecture \\
\hline & $\begin{array}{l}\text { Teaching and } \\
\text { School Libraries }\end{array}$ & 6 & & 2 & Lecture \\
\hline & \begin{tabular}{|l} 
Reading and \\
Human \\
Enrichment
\end{tabular} & 3 & & 2 & Lecture \\
\hline & $\begin{array}{l}\text { Utilization of } \\
\text { School Library } \\
\text { Media }\end{array}$ & 4 & & 2 & Lecture \\
\hline
\end{tabular}

The EFL curriculum for pre-service education for secondary education (English Department) meets all of the requirements of the current curriculum standard for pre-service teacher education for secondary education. However, as it was developed in FY 2012, it is possible that it does not meet the requirements of the next curriculum standard and the Core Curriculum for English education.

Therefore, diagnostic evaluation was conducted in order to check if the EFL curriculum satisfies the requirements of the Core Curriculum for English education. Table V shows the results of the diagnostic evaluation

TABLE V: RESUlTS OF THE DiAgNOSTIC EVALUATION OF THE EFL

CURRICULUM FOR PRE-SERVICE TEACHER EDUCATION FOR SECONDARY EDUCATION (DEPARTMENT OF ENGLISH LANGUAGE)

\begin{tabular}{|c|c|c|}
\hline $\begin{array}{l}\text { Subject } \\
\text { Groups }\end{array}$ & Course Details & check \\
\hline \multirow{22}{*}{$\begin{array}{l}\text { English } \\
\text { Pedagogy }\end{array}$} & "Courses of Study" & $\checkmark$ \\
\hline & School Textbooks & $\checkmark$ \\
\hline & Objectives and Plans & $\checkmark$ \\
\hline & Educational Continuity & \\
\hline & Listening & $\checkmark$ \\
\hline & Reading & $\checkmark$ \\
\hline & Speaking (Interaction, Presentation) & $\checkmark$ \\
\hline & Writing & $\checkmark$ \\
\hline & Phonics & $\checkmark$ \\
\hline & Alphabets & $\checkmark$ \\
\hline & Lexicon & $\checkmark$ \\
\hline & Grammar & $\checkmark$ \\
\hline & Cross-cultural Understanding & \\
\hline & Study of Teaching Materials & $\checkmark$ \\
\hline & ICT Integration & \\
\hline & ALTs and Team Teaching & \\
\hline & Interaction in English & $\checkmark$ \\
\hline & $\begin{array}{l}\text { Instruction Based on Students' Traits and } \\
\text { Proficiency Levels }\end{array}$ & \\
\hline & Instructional Design Based on Can-do Statements & \\
\hline & Development of Lesson Plans & $\checkmark$ \\
\hline & Evaluation, Criteria, and Grades & \\
\hline & $\begin{array}{l}\text { Assessment and Evaluation of Communication } \\
\text { Competence }\end{array}$ & $\checkmark$ \\
\hline
\end{tabular}




\begin{tabular}{|l|l|c|}
\hline \multirow{5}{*}{} & Knowledge and Utilization of SLA & \\
\hline \multirow{5}{*}{$\begin{array}{l}\text { Specialized } \\
\text { Knowledge in } \\
\text { English }\end{array}$} & Listening & $\checkmark$ \\
\hline & Reading & $\checkmark$ \\
\hline & Speaking (Interaction, Presentation) & $\checkmark$ \\
\hline & Writing & $\checkmark$ \\
\hline & Domain Integrated Language Activities & \\
\hline & Phonetics, Phonology & $\checkmark$ \\
\hline & Franca & \\
\hline & English Expression in Literature Works & \\
\hline & Cultural Diversity in Literature Works & $\checkmark$ \\
\hline & Representative Works of English Literature & $\checkmark$ \\
\hline & Cross-cultural Communication & \\
\hline & Cross-cultural Exchange & \\
\hline & History, society and culture of English-speaking \\
Countries & $\checkmark$ \\
\hline
\end{tabular}

Results of the diagnostic evaluation suggest that 37.84 percent of the contents of the EFL curriculum do not meet the requirements of the core curriculum of English education.

Especially, as the EFL curriculum focuses on teaching four skill areas: listening, reading, speaking, and writing separately, a four-skills or five domains integrated course needed to be developed.

\section{DEVElopment OF A NEW CURRICUlum}

Based on the results of the diagnostic evaluation, a five domains integrated content-based EFL curriculum which focuses on the promotion of students' interaction in English was developed in January, 2017.

Table VI shows the five domains integrated pre-service teacher education EFL curriculum for secondary education which was developed by the Department of Elementary Education of a private university in Shizuoka, Japan. In order to enhance students' interaction in English, Content and Language Integrated Learning (CLIL) was adopted in each category.

TABLE VI: TENTATIVE EFL CURRICULUM FOR PRE-SERVICE TEACHER EDUCATION FOR SECONDARY EDUCATION (DEPARTMENT OF ELEMENTARY EDUCATION)

\begin{tabular}{|c|c|c|c|c|c|}
\hline \multirow[b]{2}{*}{ Categories } & \multirow[b]{2}{*}{ Course Details } & \multirow[b]{2}{*}{ Semester } & \multicolumn{2}{|c|}{ Credits } & \multirow[b]{2}{*}{ Form } \\
\hline & & & $\begin{array}{c}\text { Compulso } \\
\text { ry }\end{array}$ & Elective & \\
\hline \multirow{5}{*}{$\begin{array}{l}\text { English } \\
\text { Linguistics }\end{array}$} & $\begin{array}{l}\text { Introduction to } \\
\text { English } \\
\text { Linguistics } \\
\end{array}$ & 2 & 2 & & Lecture \\
\hline & $\begin{array}{l}\text { English } \\
\text { Grammar for } \\
\text { Education I } \\
\end{array}$ & 3 & & 2 & Lecture \\
\hline & \begin{tabular}{|l} 
English \\
Grammar for \\
Education II \\
\end{tabular} & 5 & & 2 & Lecture \\
\hline & CLIL (TESOL) & 6 & & 1 & Seminar \\
\hline & $\begin{array}{l}\text { Special Lecture } \\
\text { on English } \\
\text { Linguistics }\end{array}$ & 7 & & 2 & Lecture \\
\hline \multirow{3}{*}{$\begin{array}{l}\text { English } \\
\text { Literature }\end{array}$} & $\begin{array}{l}\text { Introduction to } \\
\text { English } \\
\text { Literature }\end{array}$ & 2 & 2 & & Lecture \\
\hline & \begin{tabular}{|l} 
English \\
Literature I
\end{tabular} & 3 & & 2 & Lecture \\
\hline & \begin{tabular}{|l} 
English \\
Literature II
\end{tabular} & 5 & & 2 & Lecture \\
\hline
\end{tabular}

\begin{tabular}{|c|c|c|c|c|c|}
\hline & $\begin{array}{l}\text { CLIL } \\
\text { (Literature) }\end{array}$ & 6 & & 1 & Seminar \\
\hline & $\begin{array}{l}\text { Special Lecture } \\
\text { on English } \\
\text { Literature }\end{array}$ & 7 & & 2 & Lecture \\
\hline & $\begin{array}{l}\text { Listening and } \\
\text { Pronunciation }\end{array}$ & 3 & 1 & & Seminar \\
\hline & $\begin{array}{l}\text { Integrated } \\
\text { English I }\end{array}$ & 3 & & 1 & Seminar \\
\hline & $\begin{array}{l}\text { Integrated } \\
\text { English II }\end{array}$ & 4 & & 1 & Seminar \\
\hline English & $\begin{array}{l}\text { Integrated } \\
\text { English III } \\
\end{array}$ & 5 & & 1 & Seminar \\
\hline Communication & $\begin{array}{l}\text { Integrated } \\
\text { English IV }\end{array}$ & 6 & & 1 & Seminar \\
\hline & $\begin{array}{l}\text { ESAP I } \\
\text { (Education) }\end{array}$ & 6 & & 2 & Lecture \\
\hline & $\begin{array}{l}\text { ESAP II } \\
\text { (Education) }\end{array}$ & 7 & & 2 & Lecture \\
\hline & $\begin{array}{l}\text { Multidiscipline } \\
\text { English Studies }\end{array}$ & 8 & 2 & & Lecture \\
\hline & $\begin{array}{l}\text { Introduction to } \\
\text { Cross-cultural } \\
\text { Communication }\end{array}$ & 2 & 2 & & Lecture \\
\hline & $\begin{array}{l}\text { English Culture } \\
\text { I }\end{array}$ & 3 & & 2 & Lecture \\
\hline $\begin{array}{l}\text { Cross-cultural } \\
\text { Understanding }\end{array}$ & $\begin{array}{l}\text { English Culture } \\
\text { II }\end{array}$ & 4 & & 2 & Lecture \\
\hline & CLIL (Culture) & 6 & & 1 & Seminar \\
\hline & $\begin{array}{l}\text { Special Lecture } \\
\text { on English } \\
\text { Culture } \\
\end{array}$ & 7 & & 2 & Lecture \\
\hline & $\begin{array}{l}\text { English } \\
\text { Education I }\end{array}$ & 5 & 2 & & Lecture \\
\hline English & \begin{tabular}{|l|} 
English \\
Education II
\end{tabular} & 6 & 2 & & Lecture \\
\hline $\begin{array}{l}\text { I eaching } \\
\text { Methods }\end{array}$ & \begin{tabular}{|l} 
English \\
Education III \\
\end{tabular} & 7 & & 2 & Lecture \\
\hline & \begin{tabular}{|l} 
English \\
Education IV \\
\end{tabular} & 8 & & 2 & Lecture \\
\hline & $\begin{array}{l}\text { Introduction to } \\
\text { School } \\
\text { Education } \\
\end{array}$ & 1 & 2 & & Lecture \\
\hline & $\begin{array}{l}\text { Principle of } \\
\text { Education }\end{array}$ & 1 & 2 & & Lecture \\
\hline & $\begin{array}{l}\text { History of } \\
\text { Education } \\
\end{array}$ & 5 & & 2 & Lecture \\
\hline & \begin{tabular}{|l|} 
Educational \\
Psychology \\
\end{tabular} & 2 & 2 & & Lecture \\
\hline Basic Theories & $\begin{array}{l}\text { Developmental } \\
\text { Psychology }\end{array}$ & 6 & & 2 & Lecture \\
\hline & \begin{tabular}{|l|} 
Educational \\
Sociology \\
\end{tabular} & 2 & 2 & & Lecture \\
\hline & \begin{tabular}{|l|} 
Educational \\
Administration \\
\end{tabular} & 6 & & 2 & Lecture \\
\hline & $\begin{array}{l}\text { Special Needs } \\
\text { Education }\end{array}$ & 3 & 2 & & Lecture \\
\hline & \begin{tabular}{|l|} 
Curriculum \\
Studies for \\
Secondary \\
Education \\
\end{tabular} & 1 & & 2 & Lecture \\
\hline & $\begin{array}{l}\text { Theories and } \\
\text { Methods of } \\
\text { Moral Education }\end{array}$ & 3 & 2 & & Lecture \\
\hline $\begin{array}{l}\text { Subjects for } \\
\text { Educational } \\
\text { Pedagogy, }\end{array}$ & \begin{tabular}{|l|} 
Teaching \\
Methods of the \\
"Period for \\
Integrated \\
Studies" \\
\end{tabular} & 7 & 2 & & Lecture \\
\hline $\begin{array}{l}\text { Guidance and } \\
\text { Counseling }\end{array}$ & $\begin{array}{l}\text { Extra-curricular } \\
\text { Activities }\end{array}$ & 4 & 2 & & Lecture \\
\hline & \begin{tabular}{|l} 
Educational \\
Technology \\
\end{tabular} & 5 & 2 & & Lecture \\
\hline & $\begin{array}{l}\text { Theories of } \\
\text { Student } \\
\text { Guidance and }\end{array}$ & 3 & 2 & & Lecture \\
\hline
\end{tabular}




\begin{tabular}{|c|c|c|c|c|c|}
\hline & Career Guidance & & & & \\
\hline & \begin{tabular}{|l|} 
Educational \\
Counseling \\
\end{tabular} & 7 & 2 & & Lecture \\
\hline \multirow{3}{*}{$\begin{array}{l}\text { Subjects for } \\
\text { Educational } \\
\text { Practice }\end{array}$} & \begin{tabular}{|l} 
Preliminary \\
Course for \\
Teaching \\
Practice \\
\end{tabular} & 7 & 1 & & Seminar \\
\hline & \begin{tabular}{|l|} 
Teaching \\
Practice \\
\end{tabular} & 7 & 4 & & Training \\
\hline & \begin{tabular}{|l|} 
Educational \\
Practice Seminar
\end{tabular} & 8 & 2 & & Seminar \\
\hline \multirow{10}{*}{$\begin{array}{l}\text { University } \\
\text {-based Subjects }\end{array}$} & $\begin{array}{l}\text { Lesson Practice } \\
\text { Seminar }\end{array}$ & 1 & 2 & & Seminar \\
\hline & \begin{tabular}{|l} 
Research \\
Methods in \\
Education \\
\end{tabular} & 1 & 2 & & Seminar \\
\hline & \begin{tabular}{|l} 
Seminar for \\
Subject \\
Pedagogy \\
\end{tabular} & 1 & 2 & & Seminar \\
\hline & \begin{tabular}{|l} 
Volunteer \\
Studies
\end{tabular} & 2 & & 2 & Lecture \\
\hline & \begin{tabular}{|l|} 
Observation \\
Methods in \\
Education \\
\end{tabular} & 3 & 2 & & Seminar \\
\hline & \begin{tabular}{|l|} 
Local Issues in \\
Education \\
\end{tabular} & 6 & & 2 & Lecture \\
\hline & \begin{tabular}{|l|} 
Development of \\
Teaching \\
Materials \\
\end{tabular} & 6 & 2 & & Seminar \\
\hline & \begin{tabular}{|l|} 
School \\
Volunteer
\end{tabular} & 1 & & 2 & Training \\
\hline & \begin{tabular}{|l|} 
Outdoor \\
Education
\end{tabular} & 3 & & 2 & Lecture \\
\hline & \begin{tabular}{|l|} 
Overseas \\
Teaching \\
Practice \\
\end{tabular} & 3 & & 2 & Training \\
\hline
\end{tabular}

\section{RESUlts}

With the purpose of illustrating the content validity of the tentative EFL curriculum for pre-service teacher education for secondary education (English), formative evaluation was conducted. The Course Details of the tentative curriculum was checked if they meet the requirements of the Core Curriculum for English Education. Table VII shows the results of the formative evaluation.

TABLE VII: RESUltS OF THE Formative EVALUATION OF THE TENTATIVE EFL CURRICULUM FOR PRE-SERVICE TEACHER EDUCATION FOR SECONDARY EDUCATION (DEPARTMENT OF ELEMENTARY EDUCATION)

\begin{tabular}{|c|c|c|}
\hline Subject Group & $\begin{array}{l}\text { Course Details of the Core } \\
\text { Curriculum }\end{array}$ & $\begin{array}{l}\text { Course Details of the } \\
\text { Tentative Curriculum }\end{array}$ \\
\hline \multirow{16}{*}{$\begin{array}{l}\text { English } \\
\text { Pedagogy }\end{array}$} & "Courses of Study" & English Education I \\
\hline & School Textbooks & English Education I \\
\hline & Objectives and Plans & English Education I \\
\hline & Educational Continuity & English Education I \\
\hline & Listening & English Education II \\
\hline & Reading & English Education II \\
\hline & $\begin{array}{l}\text { Speaking (Interaction, } \\
\text { Presentation) }\end{array}$ & English Education II \\
\hline & Writing & English Education II \\
\hline & Phonics & English Education II \\
\hline & Alphabets & English Education II \\
\hline & Lexicon & English Education II \\
\hline & Grammar & English Education II \\
\hline & Cross-cultural Understanding & English Education III \\
\hline & Study of Teaching Materials & English Education I \\
\hline & ICT Integration & English Education IV \\
\hline & ALTs and Team Teaching & English Education IV \\
\hline
\end{tabular}

\begin{tabular}{|c|c|c|}
\hline & Interaction in English & English Education III \\
\hline & $\begin{array}{l}\text { Instruction Based on Students' } \\
\text { Traits and Proficiency Levels }\end{array}$ & English Education III \\
\hline & $\begin{array}{l}\text { Instructional Design Based on } \\
\text { Can-do Statements }\end{array}$ & English Education III \\
\hline & Development of Lesson Plans & English Education III \\
\hline & Evaluation, Criteria, and Grades & English Education IV \\
\hline & $\begin{array}{l}\text { Assessment and Evaluation of } \\
\text { Communication Competence }\end{array}$ & English Education IV \\
\hline & $\begin{array}{l}\text { Knowledge and Utilization of } \\
\text { SLA }\end{array}$ & $\begin{array}{l}\text { CLIL（TESOL）, English } \\
\text { Education I }\end{array}$ \\
\hline \multirow{14}{*}{$\begin{array}{l}\text { Specialized } \\
\text { Knowledge in } \\
\text { English }\end{array}$} & Listening & $\begin{array}{l}\text { Integrated English I, II, III, } \\
\text { IV }\end{array}$ \\
\hline & Reading & $\begin{array}{l}\text { Integrated English I, II, III, } \\
\text { IV }\end{array}$ \\
\hline & $\begin{array}{l}\text { Speaking (Interaction, } \\
\text { Presentation) }\end{array}$ & $\begin{array}{l}\text { Integrated English I, II, III, } \\
\text { IV }\end{array}$ \\
\hline & Writing & $\begin{array}{l}\text { Integrated English I, II, III, } \\
\text { IV }\end{array}$ \\
\hline & $\begin{array}{l}\text { Domain Integrated Language } \\
\text { Activities }\end{array}$ & $\begin{array}{l}\text { Multidiscipline English } \\
\text { Studies }\end{array}$ \\
\hline & Phonetics, Phonology & $\begin{array}{l}\text { Introduction to English } \\
\text { Linguistics }\end{array}$ \\
\hline & English Grammar & $\begin{array}{l}\text { English Grammar for } \\
\text { Education I, II }\end{array}$ \\
\hline & $\begin{array}{l}\text { History of English Language, } \\
\text { English as a Lingua Franca }\end{array}$ & $\begin{array}{l}\text { Special Lecture on English } \\
\text { Linguistics }\end{array}$ \\
\hline & $\begin{array}{l}\text { English Expression in Literature } \\
\text { Works }\end{array}$ & English Literature I, II \\
\hline & $\begin{array}{l}\text { Cultural Diversity in Literature } \\
\text { Works }\end{array}$ & English Literature I, II \\
\hline & $\begin{array}{l}\text { Representative Works of } \\
\text { English Literature }\end{array}$ & $\begin{array}{l}\text { Introduction to English } \\
\text { Literature }\end{array}$ \\
\hline & Cross-cultural Communication & \begin{tabular}{|l|} 
Introduction to \\
Cross-cultural \\
Communication \\
\end{tabular} \\
\hline & Cross-cultural Exchange & Overseas Teaching Practice \\
\hline & $\begin{array}{l}\text { History, society and culture of } \\
\text { English-speaking Countries }\end{array}$ & English Culture I, II \\
\hline
\end{tabular}

Results of the formative evaluation suggest that all of the contents of the tentative EFL curriculum meet the requirements of the core curriculum of English education.

\section{DISCUSSION AND CONCLUSION}

The purpose of the study was to develop and examine the validity of a five domains integrated content-based language learning curriculum for Japanese pre-service teachers.

Results of the formative evaluation revealed that all of the contents of the tentative EFL curriculum meet the requirements of the core curriculum of English education.

Along with the development of a five domains integrated content-based language learning curriculum, future attempts should focus on investigating pedagogical methods and techniques to increase pre-service teachers' teaching abilities. It is expected to specify the change of English teachers' roles in five domains integrated content-based language learning in order to promote elementary and secondary students' English proficiency.

\section{ACKNOWLEDGMENT}

This work was supported by JSPS KAKENHI: Grant-in-Aid for Scientific Research (C), Grant Number 26370729 


\section{REFERENCES}

[1] Ministry of Education, Science and Culture, Japan's Modern Educational System, Tokyo: Ministry of Education, Culture, Sports, Science and Technology, ch. 6, 1980.

[2] Central Council for Education, The Model for Japanese Education in the Perspective of the Twenty-first Century, Tokyo: Central Council for Education, part 2, ch. 1, 1996.

[3] Ministry of Education, Culture, Sports, Science and Technology, Japanese Government Policies in Education, Science, Sports and Culture 1996, Tokyo: Ministry of Education, Culture, Sports, Science and Technology, ch. 3, 1996.

[4] Ministry of Education, Culture, Sports, Science and Technology. (2010). "Zest for living": Pamphlet for Parents. [Online]. Available: http://www.mext.go.jp/a_menu/shotou/new-cs/pamphlet/_icsFiles/afi eldfile/2011/07/26/1234786_1.pdf

[5] Central Council for Education, Curriculum Standards for Elementary and Secondary Education: Inquiry, Tokyo: Ministry of Education, Culture, Sports, Science and Technology, 2014.

[6] Central Council for Education. Promoting School Teachers' Qualities and Abilities for the Future of School Education: in Order to Develop a Teacher Education Community in which Teachers Learn from and Improve Each Other (Report), Tokyo: Ministry of Education, Culture, Sports, Science and Technology, 2015.

[7] Commission of the Development of Foreign Language Proficiency, Five Proposals and Specific Measures for Developing Proficiency in English for International Communication, Tokyo: Ministry of Education, Culture, Sports, Science and Technology, 2011.

[8] Ministry of Education, Culture, Sports, Science and Technology, English Education Reform Plan Corresponding to Globalization,
Tokyo: Ministry of Education, Culture, Sports, Science and Technology, 2013.

[9] Central Council for Education, Promotion of School Teachers' Qualities and Abilities for School Education in the Future: Report, Tokyo: Ministry of Education, Culture, Sports, Science and Technology, 2015.

[10] Ministry of Education, Culture, Sports, Science and Technology, Act for Enforcement of the Education Personnel Certification Act, Tokyo: Ministry of Education, Culture, Sports, Science and Technology, 2009.

[11] Tokyo Gakugei Univesity, Research Project for the Promotion of English Teachers' English Skills and English Teaching Skills: AY 2015 Report, Tokyo: Tokyo Gakugei University.

[12] Tokyo Gakugei Univesity, Research Project for the Promotion of English Teachers' English Skills and English Teaching Skills: AY 2016 Report, Tokyo: Tokyo Gakugei University.

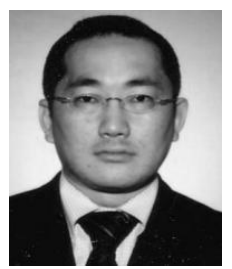

Hiroki Yoshida was born in Nara, Japan in 1973. He received the MEd in educational methodology (audio-visual education) from International Christian University, Tokyo, Japan in 2001.

He worked at the Japan Audio Visual Education Association (JAVEA) from April, 2000 to March, 2002. He has been teaching pre-service teachers in Tokoha University in Shizuoka, Japan from April, 2002 to March, 2017. He is currently a professor at the College of Intercultural Studies, Kanto Gakuin University. His research interests include teacher education, English education, online learning, cooperative learning, and hypermedia education. 